\title{
Sosialisasi Gerakan Masyarakat Hidup Sehat di Desa Bulutellue Kabupaten Sinjai Provinsi Sulawesi Selatan
}

\author{
Abdul Rahman*, Firdaus W. Suhaeb, Najamuddin \\ Fakultas Ilmu Sosial, Universitas Negeri Makassar \\ *Corresponding Author: abdul.rahman8304@unm.ac.id
}

\begin{abstract}
The purpose of this community service activity is to provide an understanding to the community about the need to implement the Healthy Living Community Movement (Germas) by keeping the environment clean and consuming good and healthy food and drinks. The method used is the method of socialization, education, and community performance through community service activities. The results of the dedication show that this activity received the attention and support of the government and the community of Bulutellue Village. Based on observations at the community service location, the community has adopted a healthy lifestyle as an implementation of Germas.
\end{abstract}

\section{Article History:}

Received: $12-03-2021$

Reviewed: 14-04-2021

Accepted: 24-04-2021

Published: 05-05-2021

\section{Key Words:}

Healthy Living Behavior,

Environmental

Cleanliness, Balanced

Nutrition.

\section{Sejarah Artikel:}

Diterima: 12-03-2021

Direview: 14-04-2021

Disetujui: 24-04-2021

Diterbitkan: 05-05-2021

\section{Kata Kunci:}

Perilaku Hidup Sehat, Kebersihan Lingkungan, Gizi Seimbang.

How to Cite: Rahman, A., Suhaeb, F., \& Najamuddin, N. (2021). Sosialisasi Gerakan Masyarakat Hidup Sehat di Desa Bulutellue Kabupaten Sinjai Provinsi Sulawesi Selatan. Jurnal Pengabdian UNDIKMA, 2(1), 9-17. doi:https://doi.org/10.33394/jpu.v2i1.3728

doi:https://doi.org/10.33394/jpu.v2i1.3728

This is an open-access article under the CC-BY-SA License.

\section{Pendahuluan}

Konstitusi mengamanahkan kepada pemerintah untuk memberikan dan meningkatkan kualitas kehidupan masyarakat dalam berbagai sektor, termasuk dalam bidang kesehatan. Pembangunan kesehatan secara tegas dinyatakan dalam Undang-Undang Nomor 25 tahun 2014 tentang Sistem Perencanaan Pembanguna Nasional. Undang-undang tersebut menyatakan bahwa pembangunan kesehatan bertujuan untuk meningkatkan kesadaran, kemauan dan kemampuan hidup sehat bagi masyarakat, agar tercipta derajat kesehatan warga masyarakat yang bermutu, sebagai modal dasar pembangunan nasional yang produktif secara sosial dan ekonomis. Konstitusi tersebut kemudian diturunkan dalam bentuk program dan kebijakan yang diharapkan dapat menjangkau masyarakat umum. Adapun turunan tersebut termaktub dalam program Indonesia sehat dengan mengedepankan 3 pilar utama paradigma sehat yaitu: 1) pengarusutamaan kesehatan dalam pembangunan, 2) penguatan pelayanan kesehatan melalui peningkatan akses pelayanan kesehatan, 3) perluasan sasaran dan benefit serta kendali mutu dan kendali biaya. 
Dalam pelaksanaan pembangunan kesehatan telah ditetapkan bahwa sistem kesehatan nasional merupakan pengelolaan kesehatan yang dilaksanakan oleh seluruh komponen bangsa baik dari kalangan pemerintahan, tenaga kesehatan, dan masyarakat umum (Primasari, 2015). Komponen tersebut harus saling membahu agar tercipta sebuah sistem yang terpadu dan saling mendukung agar tercipta derajat kesehatan masyarakat yang tinggi (Henryk, 2013). Hingga saat ini, harus diakui bahwa telah terjadi perkembangan dalam pembangunan kesehatan dalam pelaksanaan sistem kesehatan nasional, tetapi masih tersisa banyak hambatan yang harus diatasi dalam rangka mencapai tujuan pembangunan kesehatan yang telah diamanahkan oleh konstitusi (R. N. Putri, 2019). Adapun persoalan yang masih menghambat sistem kesehatan nasional saat ini ialah: 1) belum optimalnya keterjangkauan upaya kesehatan, mutu dan pemerataan, 2) masih terdapatnya sistem manajemen dan informasi serta regulasi kesehatan yang kurang kuat, 3) pembangunan kesehatan yang belum ditunjang secara penuh oleh pemerataan sumber daya manusia dan tenaga kesehatan, 4) masih terbatasnya penggalian pembiayaan dan pengalokasian serta pembiayaan kesehatan, 5) pengembangan dan pembangunan kesehatan belum optimal baik dari sisi sarana, prasarana, dan sumber daya manusia (Rachmat, 2019).

Terdapat beberapa kendala dalam tata kelola sistem kesehatan nasional, bukan berarti pemerintah berdiam diri begitu saja. Pemerintah, melalui Kementerian Kesehatan terus bergerak berupaya melakukan peningkatan derajat kesehatan masyarakat, karena hal ini terkait dengan investasi bagi pembangunan nasional (Luthfia \& Alkhajar, 2019). Pembangunan kesehatan dilaksanakan melalui berbagai kegiatan, seperti peningkatan sarana dan prasarana kesehatan, anggaran kesehatan, sumber daya manusia kesehatan, ketersediaan obat dan makanan serta alat kesehatan, dan sistem informasi dan manajemen kesehatan (N. E. Putri, 2014). Pembangunan kesehatan juga diusahakan dengan melakukan kegiatan pemberdayaan masyarakat yang menganut dan mengedepankan nilai-nilai kerakyatan, humanis, tanggap, efektif, dan bersih.

Salah satu program yang diluncurkan oleh pemerintah dalam menyukseskan sistem kesehatan nasional ialah Gerakan Masyarakat Hidup Sehat (Germas). Program ini digagas sebagai aksi tanggap dalam mengatasi masalah kesehatan yang masih menjadi pekerjaan rumah bagi pemerintah. Tiga persoalan pokok dalam tata kelola kesehatan yaitu: pemberantasan penyakit infeksi, bertambahnya kasus penyakit yang tidak menular, dan kemunculan kembali jenis penyakit yang seharusnya dapat ditangani. Gerakan Masyarakat Hidup Sehat juga ditujukan kepada masyarakat yang bermukim di wilayah perdesaan, karena beberapa jenis penyakit tidak menular misalnya diabetes, kanker, dan jantung koroner mulai dijumpai pada masyarakat desa, di samping penyakit menular yang masih sering melanda masyarakat desa (Trisnowati, 2018). Germas merupakan aksi yang bertujuan untuk memasyarakatkan kebiasan hidup sehat serta meninggalkan kebiasaan yang tidak sehat. Program Germas yang ditujukan kepada masyarakat perdesaan dibarengi dengan tiga program utama yaitu penyediaan air bersih, penyediaan instalasi kesehatan dan penataan dan pembangunan pemukiman yang layak huni.

Urgensi pembangunan kesehatan pada tingkat perdesaan turut pula diperkuat oleh Kementerian Desa, Pembangunan Daerah Tertinggal dan Transmigrasi. Program pembangunan kesehatan berbasis perdesaan telah ditetapkan sebagai suatu kebijakan melalui Program Perdesaan Sehat (Ulumiyah, 2013). Atas dasar hal itu, program ini dinilai sangat penting dalam mempercepat pembangunan perdesaan dalam bidang kesehatan masyarakat, sehingga harus dimulai dari desa, karena desa merupakan kekuatan dari negara dan di desa pula masyoritas masyarakat Indonesia sehingga desa harus menjadi prioritas sesungguhnya 
dari rencana implementasi pembangunan nasional (Sumodiningrat \& Wulandari, 2016). Program perdesaan sehat yang telah diluncurkan tersebut memiliki 5 prioritas sebagai wujud intervensi pembangunan perdesaan dalam bidang kesehatan yaitu: ketersediaan dokter di setiap pusat kesehatan masyarakat (Puskesmas), Ketersediaan bidan di setiap desa, ketersediaan air bersih di sekitar pemukiman warga, ketersediaan sarana MCK (sanitasi), dan pemenuhan gizi seimbang bagi bayi, ibu hamil dan menyusui (Tumaji \& Putro, 2018). Gerakan Masyarakat Hidup Sehat beriringan pula dengan program Desa Sehat Mandiri yang dalam perspektif kesehatan bertolak pada desa siaga, desa yang sehat, peduli dan tanggap terhadap permasalahan kesehatan di wilayahnya (Maharani et al., 2018).

Disadari bersama bahwa dalam memberikan penyadaran bagi masyarakat perdesaan terkait dengan pola hidup sehat, diperlukan pula peran serta insan akademik, termasuk dari kalangan perguruan tinggi. Upaya meningkatkan kesadaran masyarakat, salah satunya dilakukan dengan cara melakukan kegiatan pengabdian masyarakat di Desa Bulutellue, yakni mensosialisasikan gerakan masyarakat sehat. Kegiatan ini dianggap penting karena realitas menunjukkan bahwa dijumpai beberapa warga yang terkena penyakit hipertensi, diabetes, diare, dan malaria. Hal ini diduga terjadi karena pola hidup masyarakat yang mengabaikan kedisipilinan dalam kegiatan komsumsi, serta kurangnya perhatian terhadap kondisi kebersihan lingkungan.

Tujuan pengabdian ini ialah untuk memberikan pemahaman kepada masyarakat Desa Bulutellue akan pentingnya melaksanakan program Gerakan Masyarakat Hidup Sehat yang diinisiasi oleh Kementerian Kesehatan Republik Indonesia. Dengan adanya pengabdian ini, tentunya diharapakan kepada masyarakat untuk mempraktikkan pola hidup sehat dalam kehidupan sehari-hari dengan cara rutin membersihkan lingkungan sekitar yakni halaman, pekarangan, saluran air, dan kandang ternak. Selain itu, pengabdian ini bertujuan pula untuk memberikan pemahaman kepada masyarakat untuk mengkomsumsi makanan dan minuman yang baik dan menyehatkan misalnya buah-buahan dan sayuran serta menjauhi komsumsi minuman keras yang mengandung alkohol.

\section{Metode Pengabdian}

Kegiatan pengabdian ini berlokasi di Desa Bulutellue, Kecamatan Bulupoddo, Kabupaten Sinjai Provinsi Sulawesi Selatan. Kegiatan ini dilaksanakan dengan menjalin kerjasama dengan aparat pemerintah Desa Bulutellue dan melibatkan pula pegawai pusat kesehatan masyarakat (Puskesmas) Bulupoddo. Kegiatan pengabdian direncanakan, dilaksanakan, dan dievalusi selama kurang lebih 5 bulan yakni mulai November 2020-Maret 2021 atas fasilitasi dari Fakultas Ilmu Sosial dan Lembaga Penelitian dan Pengabdian Masyarakat Universitas Negeri Makassar.

Kegiatan pengabdian ini dilakukan dengan metode sosialisasi yang terdiri atas beberapa tahap, antara lain:

1) Perencanaan kegiatan

Tahapan awal dari kegiatan pengabdian ini ialah menjalin komunikasi dan koordinasi dengan Pemerintah Desa Bulutellue dengan cara mengajukan surat permohonan izin kegiatan pengabdian. Kegiatan selanjutnya ialah menyusun analisis permasalahan dan kebutuhan masyarakat desa yang terkait dengan kesehatan. Setelah mendapat persetujuan dari pemerintah Desa Bulutellue dan ditemukannya permasalahan yang terkait dengan kesehatan, maka tim pengabdian menyusun proposal pengabdian untuk mendapatkan legitimasi dari Dekan Fakultas Ilmu Sosial dan Ketua Lembaga Penelitian dan Pengabdian Masyarakat (LPPM) Universitas Negeri Makassar. 


\section{2) Persiapan}

Dalam tahapan ini, tim pengabdian mengadakan beberapa kegiatan antara lain: melakukan survey lokasi kegiatan dalam mempersiapkan tempat pelaksanaan kegiatan pengabdian, melakukan koordinasi dengan aparat pemerintah desa untuk menyampaikan undangan kepada beberapa pihak yang hendak dilibatkan dalam kegiatan pengabdian, dan mempersiapkan materi yang akan disosialisasikan kepada masyarakat.

3) Sosialisasi

Sebelum melaksanakan kegiatan pengabdian, dalam hal ini penyampaian materi pengabdian kepada masyarakat, tim pengabdian ditemani oleh salah satu aparat desa melakukan kunjungan kepada tokoh-tokoh masyarakat misalnya kepala dusun, imam kampung, kelompok pemuda, dan beberapa kepala rumah tangga untuk menyampaikan maksud dan tujuan kegiatan pengabdian. Hal ini penting agar kegiatan ini diharapkan mendapat perhatian dan dukungan dari masyarakat.

4) Pelaksanaan Kegiatan

Tahapan ini merupakan inti dari kegiatan pengabdian. Gerakan Masyarakat Hidup Sehat dalam upaya mewujudkan masyarakat yang sadar akan pentingnya pola hidup dan lingkungan sehat. Melalui kegiatan ini tim melakukan proses edukasi dan sosialisasi yang terkait dengan pola hidup sehat. Edukasi dimaksudkan sebagai upaya untuk memberikan pemahaman kepada masyarakat akan pentingnya menjaga pola hidup sehat dan kebersihan lingkungan, terutama lingkungan di sekitar pemukiman agar dapat memperoleh udara dan hawa yang masih segar. Bentuk edukasi yang dilaksanakan ialah dengan mendatangi beberapa rumah tangga yang telah disurvey terlebih dahulu. Tim melakukan dialog dengan mereka untuk memberikan informasi kepada mereka mengenai pentingnya menjaga kesehatan fisik dan kesehatan lingkungan di tengah masih mewabahnya corona. Selain itu tim juga memberikan pemahaman mengenai pola hidup sehat agar dapat mencegah penyakit lain misalnya hipertensi, diare, dan serangan penyakit jantung.

Metode yang kedua ialah metode sosialisasi. Adapun bentuk sosialisai ialah mengundang beberapa orang di rumah kepala dusun dengan tetap memperhatikan protokol kesehatan. Kegiatan ini dilakukan dengan mengundang narasumber dari Puskesmas Bulupoddo untuk memberikan pemahaman tentang pola makan sehat dan pentingnya memelihara kebersihan lingkungan. Bentuk lain dari metode sosialisasi ialah memasang poster di pos ronda, teras /beranda rumah dan beranda masjid yang memberikan informasi mengenai Gerakan Masyarakat Hidup Sehat. Metode yang ketiga ialah bekerja bakti bersama masyarakat. Kerja bakti ini berupa penyemprotan disinfektan di sekitar pada rumah warga maupun fasilitas umum misalnya pos ronda dan masjid. Terdapat 3 dusun yaitu Dusun Satengah, Dusun Alehanuae, dan Dusun Tana Tekko yang menjadi sasaran penyemprotan desinfektan.
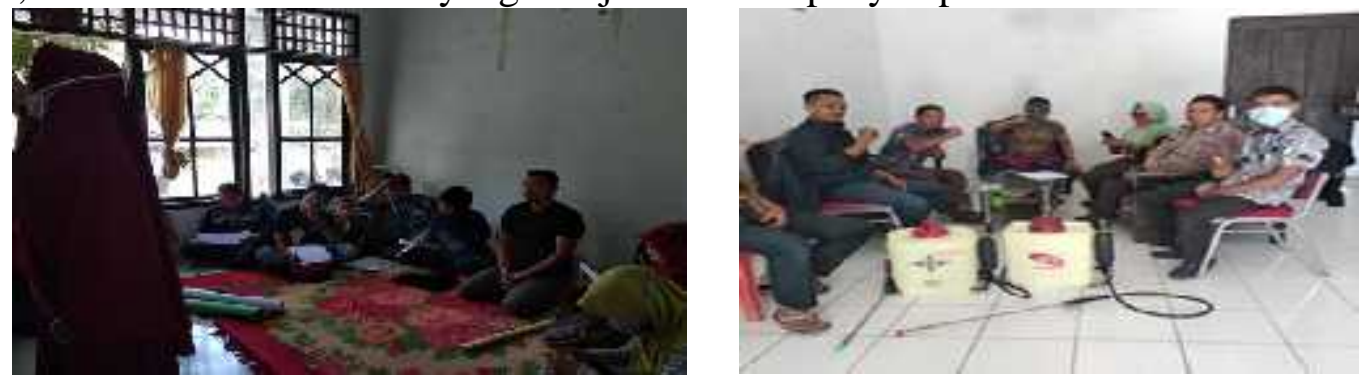

Gambar 1. Pelaksanaan Kegiatan Sosialisasi Germas kepada Masyarakat 


\section{5) Evaluasi}

Pada hari ahad, 14 Maret 2021, masyarakat, terutama anak-anak usia sekolah mulai melaksanakan kegiatan fisik, misalnya lari-lari kecil di sekitar rumah. Sementara orang tua lebih banyak melaksanakan kegiatan pembersihan halaman maupun kandang ternak yang ada di sekitar rumah. Masyarakat pun mulai memanfaatkan lahan pekarangan untuk menanam tanaman sayuran dalam hal pemenuhan gizi berimbang di rumah tangga. Selain itu, pekarangan juga dimanfaatkan untuk menanam tanaman obat yang dapat dijadikan sebagai pertolongan pertama pada penyakit dan bumbu dapur. Hal ini berarti bahwa kegiatan pengabdian yang dilaksanakan mendapat respon yang positif dari masyarakat.

\section{Hasil Pengabdian dan Pembahasan}

Gerakan Masyarakat Hidup Sehat (Germas) yang disosialisasikan pada masyarakat Desa Bulutellue merupakan upaya mengenalkan kepada masyarakat akan pentingnya praktik pola hidup sehat atas dasar kesadaran sebagai hasil dari pembelajaran yang menjadikan setiap individu tau keluarga untuk mengambil tindakan pertolongan secara cepat dan tepat di bidang kesehatan dan berperan aktif dalam mewujudkannya di tengah masyarakat. Penyuluhan atau sosialisasi telah dilakukan kepada masyarakat Desa Bulutellue selama 3 hari. Masyarakat bersama aparat pemerintah Desa begitu antusias dalam mengikuti kegiatan sosialisasi. Dalam kegiatan pengabdian ada beberapa hal yang disampaikan oleh tim yang terdiri atas dosen dari Fakultas Ilmu Sosial Universitas Negeri Makassar yang didukung dan dibantu oleh salah satu pegawai dari Puskesmas Bulupoddo. Adapun materi yang disampaikan antara lain:

1) Pengenalan logo Germas dan maknanya

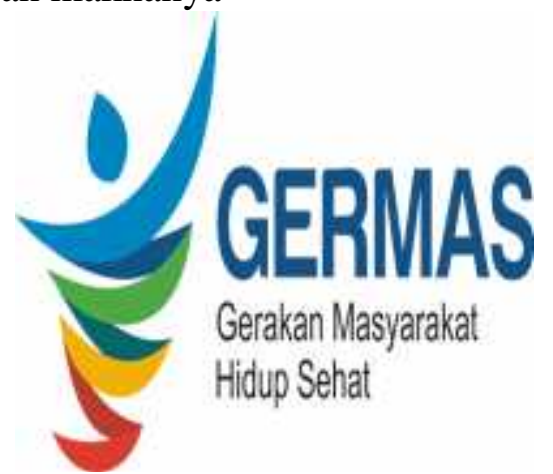

Gambar 2. Logo Germas

Sumber: https://promkes.kemkes.go.id/germas

Agar kegiatan pengabdian ini menarik bagi masyarakat maka tim menampilkan logo Gerakan Masyarakat Hidup Sehat berserta maknanya. Dalam setiap kegiatan pertemuan dengan masyarakat maka tim menyampaikan pula makna dari logo tersebut dengan menggunakan Bahasa Bugis agar lebih mudah dipahami oleh masyarakat. Adapun makna logi tersebut adalah: (a) menggambarkan masyarakat Indonesia, termasuk masyarakat yang bermukim di Desa Bulutellue untuk bersedia menjalankan dan mendukung Gerakan Masyarakat Hidup Sehat; (b) logo germas yang terdiri atas pita empat warna yang saling menyambung menunjukkan bahwa dalam mewujudkan masyarakat yang sehat, termasuk di Desa Bulutellue perlu ada kerjasama yang kuat dengan berbagai unsur masyarakat yakni Kementerian Kesehatan atau lembaga, dunia usaha, organisasi dan kelompok masyarakat, serta akademisi dalam hal ini dosen dari perguruan tinggi dan guru dari tingkat sekolah; (c) warna-warna 
yang terlihat dalam logo Germas menandakan bahwa itu merupakan warna makanan yang sehat yaitu sayuran dan buah untuk dikomsumsi dan sangat bermanfaat bagi kesehatan dan ketahanan tubuh. Makanan tersebut sangat mudah diperoleh di lingkungan perdesaan yang masih jauh dari pencemaran dan polusi udara.

2) Manfaat Gerakan Masyarakat Hidup Sehat (Germas)

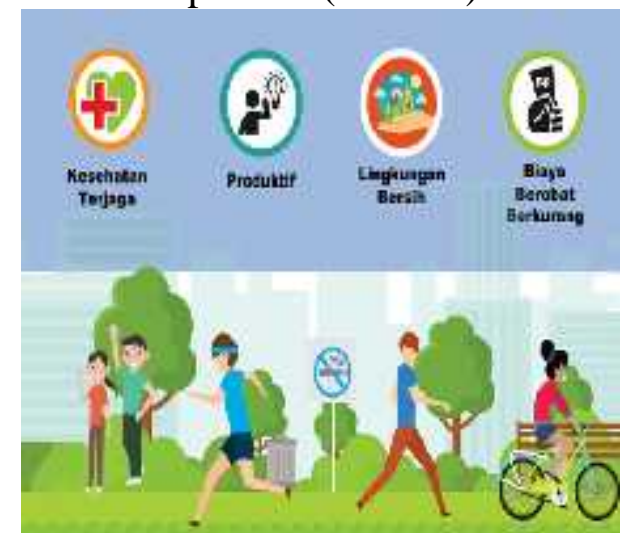

Gambar 3. Manfaat Germas

Sumber: https://promkes.kemkes.go.id/germas

Ketika bersosialisasi dengan masyarakat disampaikan pula tentang arti penting atau manfaat ketika melaksanakan Germas antara lain; (a) kesehatan terjaga, artinya bahwa Tuhan telah menitipkan kesehatan sebagai salah satu nikmat yang harus disyukuri oleh manusia. Kesehatan tersebut harus dijaga dengan mengkomsumsi makanan dan minuman yang halal dan baik untuk kesehatan, menjauhi kebiasaan tidur larut malam, dan istirahat yang cukup baik di siang hari maupun di malam hari; (b) produktif, melalui pola atau Germas, seseorang dapat melakukan kegiatan produktif dalam hal ini bekerja di sawah dan di ladang bagi petani, mengurus rumah tangga dan mendidik/mengasuh anak di rumah bagi ibu rumah tangga, serta semangat dalam belajar bagi anak sekolah; (c) lingkungan bersih, dalam arti jika masyarakat mematuhi Germas maka lingkungan sekitar rumah maupun pekarangan akan terbebas dari sampah yang berserakan maupun sarang nyamuk; (d) biaya berobat berkurang, ada pepatah lebih baik mencegah daripada mengobati. Dengan diterapkannya Germas di Desa Bulutellue dalam kehidupan sehari-hari, maka masyarakat diharapkan terbebas dari berbagai macam wabah penyakit, sehingga dapat mengurangi biaya pengobatan dan dananya dapat dimanfaatkan untuk kepentingan lain misalnya pembayaran listrik dan membeli perlengkapan anak sekolah.

3) Langkah-Langkah Gerakan Masyarakat Hidup Sehat

Germas merupakan rekayasa sosial yang memiliki tujuan untuk meningkatkan kesdaran masyarakat dalam menjaga kesehatan sekaligus menjadikan masyarakat sebagai aktor perubahan agar memiliki kemampuan dalam meningkatkan kualitas tingkah laku atau kebiasaan sehari-hari dengan tujuan hidup sehat dan bersih. Secara umum ada beberapa hal yang dapat dilakukan dalam mendukung Germas yaitu: (a) melakukan aktifitas fisik. Kegiatan ini penting karena pada dasarnya tubuh manusia dirancang untuk bergerak. Melakukan pergerakan tubuh dapat menghindarkan diri dari resiko penyakit tidak menular misalnya jantung, diabetes, hipertensi dan kanker. Melakukan gerakan atau aktifitas fisik di daerah perdesaan tidaklah sulit karena pada dasarnya semua kegiatan keseharian dapat dikategorikan gerakan fisik misalnya mencangkul, mengangkat air dari sumur ke dapur, membelah kayu bakar, dan 
menyapu halaman rumah. Dengan demikian aktifitas fisik sangat gampang dilakukan, (b) komsumsi buah dan sayuran. Kemajuan teknologi transportasi telah membuka akses hubungan antara desa dan kota. Masyarakat desa kini dapat dengan leluasa menikmati makanan khas perkotaan yang serba instant dan praktis. Tetapi, harus disadari bagi masyarakat bahwa mengkomsumsi makanan praktis memanglah enak tetapi berisiko bagi kesehatan dan pertahanan tubuh. Oleh karena itu lebih baik mengkomsumsi makanan yang diolah sendiri, ditambah dengan memperbanyak komsumsi sayuran dan buah yang masih banyak dan gampang diperoleh serta tidak berbiaya tinggi, (c) tidak merokok, karena merokok dapat memberikan dampak buruk bagi kesehatan, baik terhadap diri sendiri maupun orang lain. Asap rokok yang bertebaran dapat memperburuk kualitas udara yang sangat dibutuhkan oleh manusia. Berhenti merokok merupakan bagian penting dari germas dan akan berdampak bagi diri perokok maupun orang di sekitarnya. Secara ekonomis, jika berhenti merokok, maka biaya pembeli rokok dapat dialihkan untuk menutupi biaya kehidupan rumah tangga yang lain, (d) tidak mengkomsumsi minuman beralkohol, misalnya tuak. Aktivitas masyarakat yang memanfaatkan pohon aren untuk disadap sejatinya dapat dimanfaatkan untuk kegiatan produksi gula aren. Akan tetapi ada saja masyarakat yang justru memproduksi minuman keras (tuak). Oleh karena itu, sangat diharapkan kesadaran bagi masyarakat untuk mengurangi bahkan berhenti mengkomsumsi tuak, karena selain dilarang oleh ajaran agama Islam, juga sangat berisiko bagi kesehatan ginjal. Dipahamkan kepada masyarakat bahwa ginjal akan bekerja keras untuk mengolah air tuak itu yang warnanya sangat keruh, tetapi tetap jernih ketika tubuh mengeluarkan keringat dan air seni (kencing), (e) melakukan cek kesehatan secara rutin. Dalam hal ini, masyarakat diberikan pemahaman untuk merubah persepsi bahwa nanti melakukan kunjungan ke Puskesmas ketika sudah sakit. Sejatinya setiap bulan masyarakat harus melakukan kunjungan ke Puskesmas untuk mengecek kondisi tekanan darah, gula darah, kolesterol, dan fungsi telinga, hidung, dan tenggorokan, (f) menjaga kebersihan lingkungan dengan cara membersihkan lingkungan sekitar dari sampah yang berserakan, melakukan penimbunan terhadap benda-benda yang dapat menjadi sarang nyamuk, menyediakan tempat khusus untuk pembuangan sampah, dan membersihkan saluran air limbah rumah tangga, (g) menggunakan jamban. Ketersedian jamban (WC) di setiap rumah tangga sangatlah penting. Berdasarkan pengamatan di lapangan, setiap rumah tangga telah memiliki WC. Disampaikan kepada masyarakat, agar kebersihan WC selalu dijaga. Air dalam bak WC harus dikuras minimal 3 kali dalam satu pekan, demikian juga dudukan dan lantai harus dibersihkan setiap hari.

4) Tindak Lanjut.

Berdasarkan evaluasi yang dilakukan maka perlu ada tindak lanjut terkait dengan Gerakan Masyarakat Hidup Sehat di Desa Bulutellue yakni; (1) kegiatan yang berkaitan dengan sosialisasi akan pentingnya menjaga kesehatan lingkungan dan pola hidup sehat perlu dilakukan secara berkelanjutan demi meningkatkan kewaspadaan masyarakat terhadap penyakit menular maupun yang tidak menular; (2) perlu penguatan kerjasama dengan instansi yang terkait dengan pemberdayaan masyarakat misalnya dinas kesehatan, dinas pendidikan, dan dinas sosial di tingkat kabupaten. 


\section{Kesimpulan}

Kesimpulan yang diperoleh dari hasil kegiatan pengabdian ini adalah kegiatan pengabdian berupa Sosialisasi Gerakan Masyarakat Hidup Sehat di Desa Bulutellue telah berjalan sebagaimana yang tekah direncanakan. Masyarakat beserta aparat pemerintahan desa begitu antusias mengikuti setiap kegiatan yang dilakukan. Hal ini tentu tidak terlepas dari kemampuan tim pengabdian untuk menjalin komunikasi secara intensiv kepada seluruh warga masyarakat. Pemerintah dan masyarakat Desa Bulutellue sangat berharap agar kegiatan yang serupa terus dilaksanakan oleh para akademisi dari perguruan tinggi demi membangun kesadaran bagi warga dalam memelihara kebersihan dan kesehatan lingkungan dalam mendukung program-program pembangunan yang digalakkan oleh Pemerintah Republik Indonesia.

\section{Saran}

Kesuksesan program pembangunan yang digencarkan oleh Pemerintah Republik Indonesia sangat memerlukan dukungan dari berbagai pihak, termasuk dari kalangan akadimisi perguruan tinggi. Bentuk dukungan tersebut salah satunya dengan keterlibatan dosen dalam memberikan pemahaman kepada masyarakat mengenai program-program pemerintah agar lebih muda diimplementasikan pada tataran masyarakat bawah. Oleh karena itu, sangat diharapkan agar pemerintah terus memberikan dukungan berupa penyediaan anggaran pengabdian masyarakat kepada kalangan akademisi perguruan tinggi. Khusus program Gerakan Masyarakat Hidup Sehat (Germas), terutama yang terkait dengan kebiasaan merokok pada masyarakat, kiranya ini bisa mendapat perhatian dari akademisi dan pemerintah untuk meminimalisir perilaku tersebut dengan terus mengadakan kegiatan penyuluhan kepada masyarakat. Di sarankan pula kepada dinas sosial, dinas pendidikan, dan dinas sosial Kabupaten Sinjai untuk terus melakukan kegiatan pemberdayaan masyarakat dengan rutin melakukan kunjungan kerja di setiap desa untuk mengingatkan dan mengajak masyarakat dalam mengimplementasikan Gerakan Masyarakat Hidup Sehat di lingkungan rumah tangga, di tempat kerja dan di sekolah.

\section{Daftar Pustaka}

Henryk, S. (2013). Partisipasi Masyarakat Dalam Pembangunan di Kelurahan Sungai Keledang Kecamatan Samarinda Seberang Kota Samarinda. Ejournal Ilmu Pemerintahan, 1(2), 612-625.

Luthfia, A. R., \& Alkhajar, E. N. S. (2019). Praktik Pelayanan Publik: Puskesmas Sebagai Garda Terdepan Pelayanan Kesehatan. DECISION: Jurnal Administrasi Publik, 1(2), $71-81$.

Maharani, S. I., Martanti, L. E., \& Bahiyatun, B. (2018). Kajian Pemberdayaan Masyarakat Melalui Desa Siaga Dalam Rangka Upaya Penurunan Aki Di Bergas Kabupaten Semarang. Jurnal Kebidanan, 7(15), 10-16.

Primasari, K. L. (2015). Analisis Sistem Rujukan Jaminan Kesehatan Nasional RSUD. Dr. Adjidarmo Kabupaten Lebak. Jurnal Administrasi Rumah Sakit Indonesia, 1(2).

Putri, N. E. (2014). Efektivitas Penerapan Jaminan Kesehatan Nasional Melalui BPJS dalam Pelayanan Kesehatan Masyarakat Miskin di Kota Padang. Tingkap, 10(2), 175-189.

Putri, R. N. (2019). Perbandingan Sistem Kesehatan di Negara Berkembang dan Negara Maju. Jurnal Ilmiah Universitas Batanghari Jambi, 19(1), 139-146.

Rachmat, R. H. H. (2019). Pembangunan Kesehatan dengan Menguatkan Sistem Kesehatan Nasional. Gadjah Mada University Press. 
Sumodiningrat, G., \& Wulandari, A. (2016). Membangun Indonesia Dari Desa. Media Pressindo.

Trisnowati, H. (2018). Pemberdayaan Masyarakat Untuk Pencegahan Faktor Risiko Penyakit Tidak Menular (Studi Pada Pedesaan di Yogyakarta). Hasanuddin University.

Tumaji, T., \& Putro, G. (2018). Pemanfaatan Dana Desa Untuk Pembangunan Kesehatan Di Kabupaten Pasuruan Dan Sampang. Buletin Penelitian Sistem Kesehatan, 21(3), 141151.

Ulumiyah, I. (2013). Peran pemerintah Desa Dalam Memberdayakan Masyarakat Desa (Studi Pada Desa Sumberpasir Kecamatan Pakis Kabupaten Malang). Jurnal Administrasi Publik, 1(5), 890-899. 